\title{
Occurrence of Food-born Pathogen in Vegetables Irrigated with Sewage Water and Their Biological Treatment
}

\author{
Wafaa S. Abo El-Kheer, M. K.El-Masry*, Feryala A. Abu \\ Seif* and Dina S. Abd El Badee* \\ Department of Clinical Toxicology, Faculty of Medicine and \\ *Botany Department, Faculty of Women for Arts, Science \& \\ Education, Ain Shams University Cairo, Egypt.
}

\begin{abstract}
$7 \mathrm{HE}$ USE of untreated sewage water in irrigation of vegetables represents critical problem for the environment and human health. The present study was conducted to assess the extent of bacterial contamination of two vegetables (lettuce and tomato fruits) due to irrigation with sewage water in Belbais, Al-Sharqia Governorate, Egypt. Biological treatment process for the sewage water by two algal spp. (Spirulina platensis and Chlorella vulgaris) at two different concentrations of the algae $(2.5 \mathrm{ml} /$ and $10 \mathrm{ml} / 500 \mathrm{ml}$ of sewage water) and at two different incubation periods (15 and 21 days) were done. Analysis of sewage and underground water for total coliform, fecal coliform, algae and heavy metals were done. Results showed that sewage water samples were highly contaminated than underground water. Twenty four vegetables samples (lettuce and tomato fruits) were collected from 2 fields, the first was irrigated with sewage water (6 lettuce and 6 tomato fruits samples) and the second with underground water (6 lettuce and 6 tomato samples). All samples were examined for E. coli and Salmonella spp. For lettuce irrigated with sewage 50\% of samples were contaminated with $E$.coli while for tomato irrigated with sewage 66.6 of samples were contaminated with $E$. coli and Salmonella spp., but the tomato samples irrigated with underground were 33.3 and $50 \%$ of samples were contaminated with E. coli and Salmonella spp., respectively. The highest effect of the Spirulina platensis and Chlorella vulgaris to reduce the bacterial count (total coliform and fecal coliform) and to remove Lead $(\mathrm{Pb})$ concentrations almost was of the higher concentrations with long time, while to remove the Cupper $(\mathrm{Cu})$ was at the lower concentrations with the long time for the same algae.
\end{abstract}

Keywords: Salmonella spp., E. coli, Lettuce, Tomato fruits, Sewage water, Biological, Treatment, Spirulina platensis, Chlorella vulgaris.

There is increasing evidence that consumption of fresh-served vegetables is a major factor contributing to human gastrointestinal illness, due to the potential for contamination with pathogenic microorganisms. Incidence of food-borne pathogens on vegetables and fruits varies by region and can be extremely high in some developing countries. However, substantial outbreaks continually occur in 
developed countries. The produce related illnesses cost USA up to \$39 billion annually (Scharff, 2009). United States Environmental Protection Agency (USEPA, 2012) stated that members of two bacteria groups, coliforms and fecal coliforms, are used as indicators of possible sewage contamination because they are commonly found in human and animal feces. Wide spectrum of pathogenic organisms in low quality water poses the most immediate and direct risk to public health due to the transmission of fecal bacteria and diseases such as: bacterial diarrhea, dysentery, typhoid and cholera to consumers of wastewaterirrigated produce (Plauborg et al., 2010). Consumption of fruit and vegetable products is commonly viewed as a potential risk factor for infection with enteropathogens such as Salmonella spp. and Escherichia coli O157, with recent outbreaks linked to lettuce, spinach and tomatoes (Heaton \& Jones, 2008). Girmaye et al. (2014) detected total coliform in lettuce vegetable farm and fecal coliform in cabbage due to irrigation with polluted Awash River water. World Health Organization (WHO, 2013) stated that salmonellosis is one of the most common and widely distributed food-borne diseases. Millions of human cases are reported worldwide every year and the disease results in thousands of deaths. Goldfrank et al. (2006) concluded that most common causes of food-borne disease are bacteria Salmonella spp., Shigella sp., Clostridium perfringens, Staphylococcus aureus, Campylobacter sp., Bacillus cereus, Escherichia coli, group A Streptococcus, Clostridium botulinum, Vibrio-cholera, viruses, hepatitis, $A, E, F$ and $G$, Norwalkvirus, parasites: Entamoeba histolytica, Giardia lamblia, Trichinella spiralis, chemicals and heavy metals.

Rattan et al. (2005) reported that sewage effluents contain much higher amount of $\mathrm{P}, \mathrm{K}, \mathrm{S}, \mathrm{Zn}, \mathrm{Cu}, \mathrm{Fe}, \mathrm{Mn}$ and $\mathrm{Ni}$ compared to groundwater. Rajappa et al. (2010) found that concentration of lead (Pb), copper $(\mathrm{Cu})$ and cadmium $(\mathrm{Cd})$ were below the detectable level in most of the ground water. Pathogens can enter vegetable plants and become internalized, that is, colonize some plant tissues. Early studies suggested that E. coli could be transported into the edible part of lettuce from soil through root system (Solomon et al., 2002). Salmonella Newport could be transported from contaminated roots to the aerial parts of lettuce seedlings depending on the developmental stage of the plant (Bernstein et al., 2007). Pathogens may enter aerial portion of plants through stoma, scar tissue, or wounds as a consequence of irrigation water contacting leaf surfaces or from raindrop splashes from the soil surface (Kroupitski et al., 2009; Materon et al., 2007a Mitra et al., 2009).

Hossein et al. (2014) stated that phycoremediation is the process of employing macro or microalgae to reduce the toxic pollutants from the municipal wastewater, which has many advantageous over other conventional methods, as it is low cost and environmental friendly. Olguin (2012) stated that using microalgae in sewage treatment has several advantages such as microalgae are excellent at capturing $\mathrm{CO}_{2}$ fixation, biodiesel resulted from microalgae is one of the very few biofuels with negative $\mathrm{CO}_{2}$ emissions. Also, microalgae treat sewage water Egypt. J. Microbiol. 50 (2015) 
to make it used in irrigation purposes. Abdel-Raouf et al. (2012) found that the environmental factors which were favorable for algal growth were unfavorable for the survival of coliforms. Doke et al. (2004) reported that microalgae such as Spirulina could reduce the total bacterial count from sewage water. Chen \& Pan (2005) stated that living cells of Spirulina were found to have high tolerance to lead and can be regarded as an attractive option for biosorption of heavy metal contaminant. And they added that the use of Chlorella vulgaris as a treatment provides high treatment efficiency. Bashan and Bashan (2010) evaluated C.vulgaris capacity to remove copper, nickel and lead from the wastewater.

The main objectives of this research included: a- analysis of sewage and underground water for total coliform, fecal coliform, algae and some heavy metals. b- To assess the extent of bacterial contamination of vegetables (lettuce and tomato fruits) due to irrigation with untreated sewage water. c- Biological treatment of sewage by the use of (Spirulina platensis) and (Chlorella vulgaris) to remove or decrease bacteria and heavy metals in the sewage water before using it in the irrigation of crops.

Water analysis

\section{Materials and Methods}

Samples collection

Eight water samples that used in irrigation of vegetables were collected from two water sources (sewage and underground water) in Belbais area in Al Sharqia Governorate in Egypt during July 2010 and analysis according to American Public Health Association (APHA, 2005).

\section{Samples procedures}

Enumeration of total coliform and feacal coliform were carried out by using MPN technique according to APHA (2005). Total coliform was detected on Lauryl tryptose broth (LTb). The positive tubes were confirmed on brilliant green lactose bile broth (BGLB). Feacal coliform was detected by using EC broth media and confirmed using EMB agar media.

\section{Algal detection}

All water samples (sewage and underground) were examined microscopically using a magnification of $10 \mathrm{X}$ and $40 \mathrm{X}$ for determining the algal flora in these samples according to Patrick \& Reimer (1975) and Perscott (1978).

Heavy metals analysis

The analysis had been done in the Central Laboratories for the Ministry of Electricity and Power. All water samples (sewage and 
underground) were examined for four heavy metals $(\mathrm{Cd}, \mathrm{Al}, \mathrm{Cu}$ and $\mathrm{Pb}$ ) using atomic absorption spectrophotometer according to APHA (2005).

Detection of E.coli and Salmonella spp. from vegetables (tomato fruit and lettuce)

\section{Sample collection}

Twelve samples of lettuce were collected from two fields (6 samples were irrigated with sewage water and 6 were irrigated with underground water). Another 12 samples of tomato fruit were collected from the same fields (6 were irrigated with sewage and 6 with under-ground) during July 2010. All samples were collected and immediately brought to the laboratory of microbiology for bacterial analysis. The investigatins were conducted within three hours of sample collection.

Detection of E. coli

Analysis of $E$. coli were done according to the bacteriological analytical manual (BAM) (Feng et al., 2002). Twenty five grams of tomato fruits or Lettuce were aseptically removed from each sample using a sterile scalpel and blended in $225 \mathrm{ml}$ of sterile peptone water for 2 min to make a1:10 dilution as a cell suspension and diluted. The samples $(1 \mathrm{ml})$ from each dilution series were transferred in triplicates into Lauryl tryptose broth (LTb) medium. All tubes with positive results (turbidity and gas) were sub-cultured in EC broth media. The positive tubes were confirmed on Eosin methylene blue Agar (EMBA) .Colonies that were characteristic of $E$. coli were Gram stained, streaked onto tryptic soy agar (TSA). Pure colonies were sub-cultured in peptone water, and tested for (IMVIC reactions) and Triple Sugar Iron .

Detection of Salmonella spp.

Salmonella spp. was detected according to bacteriological analytical manual (BAM) method (Feng et al., 2002). Samples (25g) were aseptically removed from each sample using a sterile scalpel and blended in $225 \mathrm{ml}$ of sterile buffered peptone water for $2 \mathrm{~min}$ as a cell suspension and incubated at $35^{\circ} \mathrm{C}$ for $24 \mathrm{hr}$ for the metabolic recovery of cells. Then inoculated into selenite cystine broth (SCB) to allow selective enrichment for Salmonella spp. Then streaked on bismuth sulphite agar (BSA), hektoen enteric agar (HEA) and Xylose Lysine Deoxycholate (XLD, Oxoid) agar. The plates were examined for typical Salmonella colonies. Two typical colonies from the selective media were inoculated into triple sugar iron (TSI) and lysine iron (LI) agar slants. Presumptive Salmonella from TSI and LI agar slants were inoculated into $10 \mathrm{ml}$ urea broth (UB), and then subjected to (IMVIC tests).

Biological treatment of sewage water by algae against bacteria and heavy metals

Two isolates of algal species (Spirulina platensis) and (Chlorella vulgaris) were used for the treatment process. Those isolates were prepared in the agricultural research center in Giza, Egypt. Two Egypt. J. Microbiol. 50 (2015) 
concentrations of Algae were 2.5 and $10 \mathrm{ml}$ per $500 \mathrm{ml}$ of sewage and were incubated at $30^{\circ} \mathrm{C}$ for two incubation periods 15 and 21 days). Total coliform and fecal coliform of sewage water were detected before and after treatment. The same procedure was repeated for detection of $\mathrm{Pb}$ and $\mathrm{Cu}$ after 15 and 21 days using atomic absorption spectrophotometer method after the treatment process with the algae.

\section{Statistical analysis}

Standard deviation has been calculated for the studied parameters. In addition, the obtained data were treated statistically using analysis of variance as described by Snedecor \& Cockran (1969). Means were compared by LSD at 5\% using SPSS program Ver. 16.

\section{Results and Discussion}

Detection of bacteria, Algae and heavy metals in sewage and underground water

Anukool \& Shivani (2011), US Environmental Protection Agency (USEPA, 2012) and United States Geological Survey (USGS, 2012) stated that the members of two bacteria groups: total coliforms (TC) and fecal coliforms (FC) are used as indicators for sewage contamination because they are commonly found in feces of human and animal. This was agreed with the present study as shown in Table 1 where it found that sewage water was highly contaminated with (TC) and (FC) bacteria and results showed that TC and FC bacteria were $\left(>50 \mathrm{x} 10^{3} \mathrm{cfu} / 100 \mathrm{ml}\right)$ in the sewage water samples. The results indicated that TC and FC count of the underground water were $(32.5+8.19$ and $43.25+3.86 / 100 \mathrm{ml})$, respectively, that exceeds the permissible limits of the Egyptian standards for drinking underground water, 2007, which must be free from coliform bacteria.

TABLE 1. Detection of total coliform (TC), fecal coliform (FC), Algal sp. and some Heavy metals for sewage and underground water.

\begin{tabular}{|l|l|c|c|}
\hline \multicolumn{2}{|c|}{ Contamination type } & Sewage water & Under ground \\
\hline \multirow{3}{*}{$\begin{array}{l}\text { Bacterial group } \\
\text { MPN/100ml }\end{array}$} & Total Coliform & $>50 \times 10^{3}$ & $32.5 \pm 8.19$ \\
\cline { 2 - 4 } $\begin{array}{l}\text { Egyptian } \\
\text { standards }\end{array}$ & Fecal coliform & $>50 \times 10^{3}$ & \\
\hline \multirow{2}{*}{ Algal sp } & & - & $43.25 \pm 3.86$ \\
\hline \multirow{3}{*}{$\begin{array}{l}\text { Heavy } \\
\text { metals }(\mathrm{mg} / \mathrm{l})\end{array}$} & & 6 genus of algae & $\mathrm{ND}$ \\
\cline { 2 - 4 } & Coad $\mathrm{Pb}$ & 0.2044 & $\mathrm{ND}$ \\
\cline { 2 - 4 } & Cadmium Cd & 0.057 & $\mathrm{ND}$ \\
\cline { 2 - 4 } & Aluminum Al & $\mathrm{ND}$ & $\mathrm{ND}$ \\
\hline
\end{tabular}

-ND: not detected 
The permissible limits of treated wastewater $\left(10^{3} \mathrm{MPN} / 100 \mathrm{ml}\right)$ stated in National Regulatory Standards for wastewater

For algae in water, Xu et al. (2008) and Burford et al. (2012) stated that the excessive nitrogen loads can stimulate excessive rates of primary production and a higher incidence of harmful algal blooms. They added that sewage nutrients increased primary productivity rates of phytoplankton due to the sedimentation of unused organic matter as stratification develops and a change in the phytoplankton species composition due to alterations in ambient nutrient ratios and quantities. This report was in the same line of the present study where different species (6 species) of algae such as: Chroococcus minutes, Oscillatoria tenuis, Anabena sp., Synedra ulna, Melosira granulate and Spirulena major were detected in the sewage water. On the other hand, the underground water samples of the present study showed no growth for any algal species due to the low concentrations of nitrates and phosphates. For heavy metals in water the present study showed that the sewage water contained higher amounts of $\mathrm{Pb}$ and $\mathrm{Cu}(0.2044$ and $0.057 \mathrm{mg} / 1$, respectively) while in ground water were not detected (table 1).This was in agreement with that of Rattan et al. (2005) who reported that sewage effluents contained much higher amount of $\mathrm{P}, \mathrm{K}, \mathrm{S}, \mathrm{Zn}, \mathrm{Cu}$, $\mathrm{Fe}, \mathrm{Mn}$ and $\mathrm{Ni}$ compared to ground water. For $\mathrm{Cd}$ and $\mathrm{Al}$ in the present study were not detected in each sewage or underground. This agree with that of Leung \& Jiao (2006) and Rajappa et al. (2010) who detected heavy metals in very low concentrations in underground water samples .

\section{Detection of Salmonella spp. and E. coli in vegetable}

Statistical analysis indicated that there is significant difference between the types of irrigation water for the presence of pathogens, as well as there is significant difference between the percentage of the recorded pathogen ( $E$. coli and Salmonella spp.) in the two vegetable crops. Results showed that 3 out of 6 samples of lettuce $(50 \%)$ that irrigated with sewage water were contaminated with $E$. coli but free from Salmonella spp. (Table 2). This was in the same line with that of Ali et al. (2013) who found that 3 out of 10 samples of retail lettuce stores (30\%) were contaminated with E. coli and Girmaye et al. ( 2014) who found that the highest total coliform count $6.6 \times 10^{6}$ was recorded from lettuce vegetable farm and faecal coliform count $5.7 \times 10^{5}$ was recorded in cabbage due to irrigation with polluted Awash River water in India On the other hand Mieke et al. ( 2014) found that Salmonella spp. prevalence in fresh-served vegetables that irrigated with water from reservoir was very high, namely $42 \%$ (20/48) in lettuce farms and $29 \%$ (14/48) in strawberries. The present investigation showed that lettuce samples which were irrigated with underground water were free from each of E .coli and Salmonella spp. According to Steele \& Odumeru (2004) and Halablab et al. (2011) who reported that ground water had a good microbial quality compared to other water sources contaminated with sewage and the level of aerobic bacteria on lettuce irrigated by river water showed statistically a higher bacterial load than samples irrigated using ground water. 
TABLE 2. Percentage of contaminated Lettuce and tomato fruit samples with $E$ coli and Salmonella spp. which irrigated with Sewage or Underground water.

\begin{tabular}{|l|c|c|c|c|}
\hline Vegetable type & $\begin{array}{c}\text { Number of } \\
\text { samples }\end{array}$ & $\begin{array}{c}\text { Irrigation water } \\
\text { type }\end{array}$ & \% of E. coli & $\begin{array}{c}\text { \% of Salmonella } \\
\text { spp. }\end{array}$ \\
\hline \multirow{2}{*}{ Lettuce } & 6 & Sewage & 50 & - \\
\cline { 2 - 5 } & 6 & Underground & - & - \\
\hline \multirow{2}{*}{ Tomato } & 6 & Sewage & 66.6 & 66.6 \\
\cline { 2 - 5 } & 6 & Underground & 33.3 & 50 \\
\hline LSD at 5\% & \multicolumn{2}{|c|}{ Water type: 2.55} & \multicolumn{2}{|c|}{ pathogen: 4.23} \\
\hline
\end{tabular}

In the present study $66.6 \%$ of tomato fruits that irrigated with sewage water were contaminated with E. coli and Salmonella spp. (Table 2). These results were agreed with that obtained by Forslund et al. (2012) who found that Salmonella has been shown to survive and grow on the surface of tomatoes and also taken up internally through stem scar where it was isolated from the tomatoes irrigated with sewage water in Italy. Also Ali et al. (2013) found that 1 out of 10 samples of tomato (10\%) was contaminated with $E$. coli. The present results of tomato fruits irrigated with underground water showed that 2 out of $6(33.3 \%)$ and 3 out of $6(50 \%)$ of samples were contaminated with E. coli or Salmonella spp. (Table 2). Manure applications have been often anecdotally implicated in creating differences in microbiological water quality of surface waters. Analysis of point source data in the survey of surface waters in southern Alberta Canada showed that predicted manure output from cattle, pig, and poultry feeding operations was directly associated with prevalence of these pathogens (Johnson et al., 2003). Microbial quality of well water can be affected by the design of wells, nature of the substrata and depth to groundwater and rainfall (Gerba, 2009). Rainfall events inevitably increase concentrations of pathogens and indicator organisms in streams, reservoirs, and ponds due to surface run off into waterways and release of bacteria from bottom sediments (Pachepsky \& Shelton, 2011). Lettuce and tomato fruits samples that irrigated with swage water appear significantly highly contaminated with $E$. coli and Salmonella spp. than that irrigated with underground water. In the same line, data showed that the number of Lettuce and tomato fruit samples which contaminated with $E$. coli were significantly high than that contaminated with Salmonella spp. (Table 2).

Biological treatment of sewage by algae is important to decrease the sewage water pollutant from pathogen and heavy metals before irrigation. Oilgae (2009), Olguin (2012) and Hossein et al. (2014) stated that algae are an important bioremediation agent that is already being used by many wastewater facilities. They added that purpose microalgae-bacteria based systems for treating wastewater. Abdel-Raouf et al. (2012) stated that the environmental factors which were favorable for algal growth were unfavorable for the survival of coliforms. So, the growth of some algal species led to decrease bacterial count. In the present study two algal species of Spirulina platensis and Chlorella vulgaris with two concentrations (2.5 and $10 \mathrm{ml} / 500 \mathrm{ml}$ sewage) at two incubation periods (15 and 21 days), for biological treatment of sewage water against bacteria (T C and FC) and heavy metals $(\mathrm{Pb}$ and $\mathrm{Cu}$ ).The highest significant effect of the Spirulina platensis and Chlorella vulgaris to 
reduce total coliform and fecal coliform was at high concentration $10 \mathrm{ml} / 500 \mathrm{ml}$ sewage with long time (21days). Where, Spirulina platensis and Chlorella vulgaris reduced 99.82 and $99.67 \%$, respectively, from the total coliform and $100 \%$ from the fecal coliform. In the same line Ahmad et al. (2013) found that the maximum reduction in total coliform was $100 \%$ by $C$. vulgaris from wastewater. On the other hand, Doke et al. (2004) reported that Spirulina sp. could reduce the total bacterial count up to $75 \%$. The present data (Table 3 ) indicated that Chlorella vulgaris is more efficient in removal heavy metals $(\mathrm{Pb}$ and $\mathrm{Cu})$ from contaminated water compared to Spirulina platensis. Spirulina platensis and Chlorella vulgaris at retention time 21day with concentration $10 \mathrm{ml} / 500 \mathrm{ml}$ significantly reduced sewage $\mathrm{Pb}$ by 96.6 and $99.02 \%$ respectively. In addition, the highest efficiency of Spirulina platensis and Chlorella vulgaris to remove $\mathrm{Cu}$ concentration were at low algal concentration $(2.5 \mathrm{ml} / 500 \mathrm{ml}$ sewage), where the removal percent is 74.04 and $84.21 \%$, respectively.

In the same line, Mansoret al. (2011) found that Spirulina is capable of removing about $64 \% \mathrm{~Pb}$ and $63 \%$ Zinc. In addition, Bashan \& Bashan (2010) evaluated the capacity of C. vulgaris to remove over $97 \%$ of copper, $91 \%$ of nickel and over $90 \%$ of $\mathrm{Pb}$ from the wastewater. Chen \& Pan (2005) stated that living cells of Spirulina were found to have high tolerance to lead and can be regarded as an attractive option for biosorption of heavy metals contaminant.

TABLE 3. Biological treatment of sewage water against total coliform ( Tc) and fecal coliform (Fc) and heavy metals ( $\mathrm{Pb}$ and $\mathrm{Cu}$ ) by algal sp. Spirulena platensis and Chlorella vulgaris at $(2.5$ and $10 \mathrm{ml} / 500 \mathrm{ml})$ concentrations for 15 and 21 days.

\begin{tabular}{|c|c|c|c|c|c|c|c|c|c|}
\hline & Before & \multicolumn{8}{|c|}{ After treatment } \\
\hline \multirow{2}{*}{$\begin{array}{l}\text { Type of algae } \\
\text { Incubation period }\end{array}$} & & \multicolumn{4}{|c|}{$\begin{array}{c}\text { Blue-green } \\
\text { alga(Spirulenaplatensis) }\end{array}$} & \multicolumn{4}{|c|}{ Green alga(Chlorella vulgaris) } \\
\hline & & \multicolumn{2}{|c|}{15 days } & \multicolumn{2}{|c|}{21 days } & \multicolumn{2}{|c|}{15 days } & \multicolumn{2}{|c|}{21 days } \\
\hline $\begin{array}{l}\text { Concentration of } \\
\text { alga }(\mathrm{ml} / 500 \mathrm{ml})\end{array}$ & & 2.5 & 10 & 2.5 & 10 & 2.5 & 10 & 2.5 & 10 \\
\hline \multirow{2}{*}{$\begin{array}{l}\text { Total coliform } \\
\text { (MPN/100ml) }\end{array}$} & $2.4 \times 10^{5}$ & $24 \times 10^{3}$ & $24 \times 10^{3}$ & 73 & 440 & $24 \times 10^{3}$ & 310 & 490 & 790 \\
\hline & $\% \mathrm{R}$ zero & $90.00 \mathrm{~b}$ & $90.00 \mathrm{~b}$ & $99.97 \mathrm{a}$ & $99.82 \mathrm{a}$ & $90.00 \mathrm{~b}$ & $99.87 \mathrm{a}$ & $99.80 \mathrm{a}$ & $99.67 \mathrm{a}$ \\
\hline \multirow{2}{*}{$\begin{array}{l}\text { Fecal coliform } \\
(\mathrm{MPN} / 100 \mathrm{ml})\end{array}$} & $2.4 \times 10^{5}$ & $9 \times 10^{3}$ & 520 & zero & Zero & $19 \times 10^{3}$ & zero & zero & 20 \\
\hline & $\% \mathrm{R}$ zero & $96.25 b$ & $99.78 \mathrm{a}$ & $100 \mathrm{a}$ & $100 \mathrm{a}$ & $92.08 \mathrm{c}$ & $99.99 a$ & $100 \mathrm{a}$ & $100 \mathrm{a}$ \\
\hline \multirow{2}{*}{$\mathrm{Pb}(\mathrm{mg} / \mathrm{l})$} & $\begin{array}{c}\text { Concentration } \\
0.2044\end{array}$ & 0.014 & 0.0136 & 0.011 & 0.008 & 0.0111 & 0.0097 & 0.0006 & 0.002 \\
\hline & \%removal & $93.2 b$ & $93.3 b$ & $94.6 \mathrm{~b}$ & $96.1 \mathrm{ab}$ & $94.6 \mathrm{~b}$ & $95.6 b$ & $97.06 \mathrm{ab}$ & $99.02 \mathrm{a}$ \\
\hline \multirow[t]{2}{*}{$\mathrm{Cu}(\mathrm{mg} / \mathrm{l})$} & $\begin{array}{c}\text { Concentration } \\
0.057\end{array}$ & 0.0234 & 0.0378 & 0.0148 & 0.0195 & 0.0149 & 0.0169 & 0.009 & 0.011 \\
\hline & \%removal & $58.95 \mathrm{~d}$ & $33.68 \mathrm{e}$ & $74.04 \mathrm{~b}$ & $65.79 \mathrm{c}$ & $73.86 \mathrm{~b}$ & $70.35 \mathrm{~b}$ & $84.21 \mathrm{a}$ & $80.70 \mathrm{a}$ \\
\hline
\end{tabular}

Percent $(\%)$ of Reduction(R) in bacterial count and percent $(\%)$ of removal in heavy metals

Egypt. J. Microbiol. 50 (2015) 


\section{Conclusion}

Sewage water highly contaminated by chemical and biological pollutants so the use of untreated sewage water in irrigation of vegetables represents critical problem for the environment and human health. The results of the study showed that the vegetables (lettuce and tomato fruits) that irrigated with sewage water were highly contaminated than that irrigated with underground water. Also the results indicated that use of Spirulina platensis and Chlorella vulgaris to remove of decrease bacteria and heavy metals in the sewage water lead to decrease in the remaining of each bacteria and heavy metals. So sewage water must be treated before using in irrigation.

\section{References}

Abdel-Raouf, N., Al-Homaidan, A. A. and Ibraheem, I. B. M. (2012) Review on microalgae and wastewater treatment. Saudi Journal Biological Science, 19, 257-275.

Ahmed, F., Khan, A.U. and Yasar, A. (2013) The potential of Chlorella vulgaris for wastewater treatment and biodesel production. Pakistan Journal Boany, 45(1), 461465 .

Ali, Y. S., Hayfaa M., AwazArshad, S. and Solin, O. H. (2013) Detection of Escherichia coli $\mathrm{O} 157$ in vegetables, Journal of Agriculture and Veterinary Science, 6(2), 16-18 .

Anukool, S. and Shivani, S. (2011) Assessment of phsico-chemical properties and sewage pollution indicator bacteria in surface water of River Gomti in Uttar Pradesh. International Journal Environmental Science, 2(1), 325-336.

APHA (American Public Health Association) (2005) Standard Methods for Examination of Water and Wastewater.

Bashan, L.E. and Bashan, Y. (2010) Immobilized microalgae for removing pollutants Review of practical aspects. Journal Biological Resource Technology, 101(6) 16111627.

Bernstein, N., Sela, S. and Neder-Lavon, S. (2007) Assessment of contamination potentialof lettuce by Salmonella enteric serovar Newport added to the plant growing medium. Journal Food Protection, 70, 1717-1722.

Burford, M. A., Revill, A. T., Smith, J. and Clementson, L. (2012) Effect of sewage nutrients on algal production, biomass and pigments in tropical tidal Creeks. Marine Pollution Bulletin, 64(12), 2671-2680.

Chen, H. and Pan, S. S. (2005) Bioremdiation potential of Spirulena, toxicity and biosorption studies of lead. Journal Zhejiang Uni. Science. 6(3), 171-174. 
Doke, J., Kalyan Raman, V. and Ghole, V.S. (2004) Treatment of anaerobically digested wastewater using Spirulena sp.. International Journal on algae, 6(4) ,7-14.

Feng, P., Weagant, S. D., Grant, M. A. and Burkhardt, W. (2002) "Bacteriological Analytical Manual: Enumeration of Escherichia coli and the Coliform Bacteria.

Forslund, A., Ensink, J. H., Markussen, B., Battilani, A., Psarras, G., Gola, S., Sandei, L., Fletcher, T. and Dalsgaard, A. (2012) Escherichia coli contamination and health aspects of soil and tomatoes (Solanum lycopersicum) subsurface drip irrigated with on-site treated domestic wastewater. Water Research, 46, 5917-5934.

Gerba, C.P. (2009) The role of water and water testing in produce safety. In. "Microbialsafety of Fresh Produce" (X. Fan, B. A. Niemira, C. J. Doona, F. E. Feeherty and R. B. Gravani, Ed.), pp. 129-142. Wiley.

Girmaye, B., Ameha, K. and Sissay, M. (2014) Assessment of bacteriological contaminants of some vegetables irrigated with Awash River water in selected farms around Adama town, Ethiopia, Journal of Microbiology and Antimicrobials, 6(2), $37-42$.

Goldfrank, L. R., Flomenbaum, N. E., Hoffman, R. S., Howland, M. A., Lewin, N. A. and Nelson, L. S. (2006) "Goldfrank' Stoxicologic Emergencies", $8^{\text {th }}$ ed.

Halablab, M. A., Sheet, I. H. and Holail, H. M. (2011) Microbiological quality of raw vegetables grown in Bekka Valley, Lebanon. American Journal Food Technology, 6(2), 129-139.

Heaton, J. C. and Jones, K. (2008) Microbial contamination of fruit and vegetables and the behavior of enteropathogens in the phyllosphere, review. Journal of Applied Microbiology, 104(3), 613-626.

Hossein, A., Kondiram, D. and Gorakh, P. (2014) Application of phycoremediation technology in the treatment of sewage water to reduce pollution load. Advances in Environmental Biology, 8(7), 2419-2423.

Kroupitski, Y., Pinto, R., Brandl, M. T., Belausov, E. and Sela, S. (2009) Interactions of Salmonella enteric with lettuce leaves . Journal Applied Microbiology, 106, 18761885.

Leung, C.M. and Jiao, J.J. (2006) Heavy metal and trace element distributions in groundwater in natural slopes and highly urbanized spaces mid-levels area. Hong Kong. Water Research, 40, 753-767.

Mansor, H., Mat, J. and Tahir, W.P. (2011) Treatment of leachate using cultured Spirulina platensis. International Journal engineering and Technology, 8(2), 57-60.

Materon, L. A., Martinez-Garcia, M. and McDonald, V. (2007) Identification of sources of microbial pathogens on cantaloupe rinds from pre-harvest to post-harvest operations. World Journal of Microbiology and Biotechnology, 23, 1281-1287.

Egypt. J. Microbiol. 50 (2015) 
Mieke, U., Ahmed, A., Siele, C. and Fouad, E. (2014) Microbiological safety of strawberries and lettuce for domestic consumption in Egypt, Journal of Food Processing and Technology, 5, 3 .

Mitra, R., Cuesta-Alonso, E., Wayadande, A., Talley, J., Gilliland, T. and Fletcher, D. J. (2009) Effect of route of introduction and host cultivar on the colonization, internalization and movement of the human pathogen Escherichia coli O157:H7 in spinach. Journal Food Protection, 72, 1521-1530.

Oilgae, B. (2009) Oilgae guide to algae-based wastewater treatment, a sample report, 6-8.

Olguin, E.J. (2012) Dual purpose microalgae-bacteria based systems that treat wastewater and produce biodesel and chemical products within a biorefinery. Biotechnology Advances, 30(5), 1031-1046.

Pachepsky, Y. and Shelton, D. (2011) Escherichia coli and fecal coliforms in freshwater and estuarine sediments. Critical Revolution Environmental Science Technology, 41, $1067-1110$.

Patrick, R. and Reimer, W.C. (1975) "Phytoplankton of United States". Department of limnology. The Academy of Natural Sciences of Philadelphia, U.S.A.

Plauborg, F., Andersen, M. N., Liu, F., Ensink, J. and Ragab, R. (2010) Safe and high quality food production using low quality waters and improved irrigation systems and management, SAFIR. Agricultural Water Management, 98(3), 377-384.

Perscott, A. G. W. (1978) "How to Know Fresh Water Algae" ( $3^{\text {rd }}$ ed.) pp. 293. Wm. C. Brown Company Publisher, Dubuque lowa.

Rajappa, B., Manjappa, S. and Puttaiah, E. T. (2010) Monitoring of heavy metal concentration in ground water of HakinakaTaluk, India. Contemporary Engineering Sciences, 3(4), 183-190.

Rattan, R. K., Datta, S. P., Chhonkar, P. K., Suribabu, K. and Singh, A. K. (2005) Long term impact of irrigation with sewage water effluents on heavy metal content in soils, crops and ground water, a case study. Agriculture, Ecosystems and Environment, 109(3-4), 310-322.

Scharff, R. (2009) Health-related costs from foodborne illness in the United States, http://www.producesafetyproject.org/media?id=0009.

Snedecor, G. W. and Cockran, W. G. (1969) “Statistical Methods". $6^{\text {th }}$ ed. Iowa Univ. Press. Ames. Iowa, U.S.A.

Solomon, E.B., Yaron, S. and Matthews, K.R. (2002) Transmission of Escherichia coli O157:H7 from contaminated manure and irrigation water to lettuce plant tissue and its subsequent internalization. Appl. Environ. Microbiol. 68, 397-400. 
Steele, M. and Odumeru, J. (2004) Irrigation water as source of food-borne pathogens on fruit and vegetables. Journal Food Protection, 67(12), 2839-2849.

USEPA (United States Environmental Protection Agency) (2012) Web Page. USMexico Border. Available online: http://www.epa.gov/usmexicoborder/index.html

USGS (2012) “United States Geological Survey”, Michigan, Water Science Centre, Quality of ground water.

WHO (2013) World Health Organization. Medical Centre, "Salmonella (non-typhoidal) Key Facts".

Xu, J., Ho, A. Y., Yin, K., Yuan, X., Anderson, D. M., Lee, J. H. and Harrison, P. J. (2008) Temporal and spatial variations in nutrient stoichiometry and regulation of phytoplankton biomass in Hong Kong waters; influence of the Pearl River outflow and sewage inputs. Marine Pollution Bulletin, 57(6-12), 335-348.

(Received 26/2/2015;

accepted 24/5/2015) 


\section{تواجد مسببات الأمراض المنقولة بالغذاء في الخضروات المروية بمياه الصرف الصحي و معالجتها بيولوجيا بالفيا في}

$$
\begin{aligned}
& \text { وفاء صبحى ابو الخير, محى قدى المصرى , فريالةعبد الحميد ابوسيف* ودينا }
\end{aligned}
$$

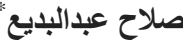

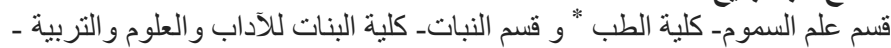

$$
\begin{aligned}
& \text { جامعة عين شمس - القاهرة - مصر. }
\end{aligned}
$$

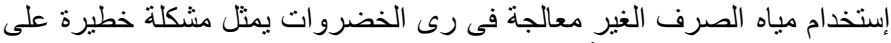

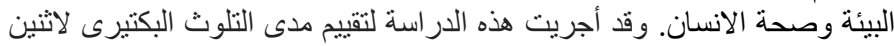

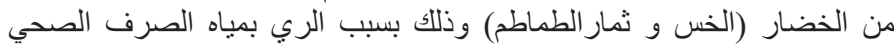

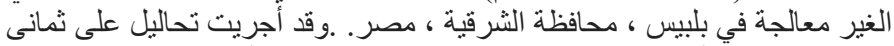

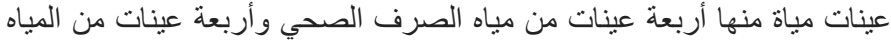

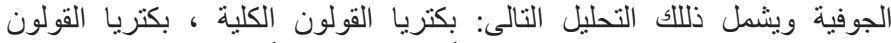

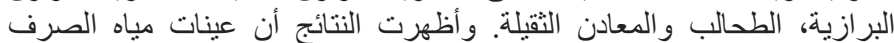
الصحي كانت ملوثة للغاية عن المياه الجوانية.

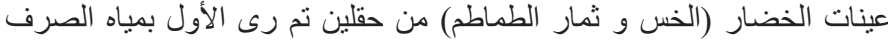

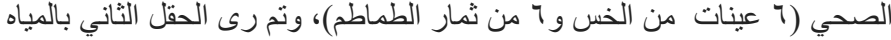

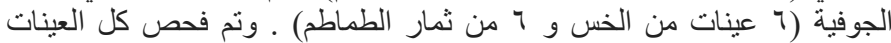

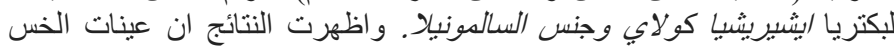

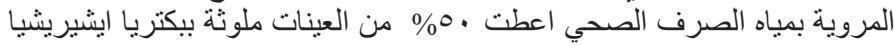

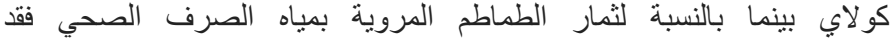

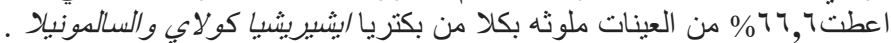

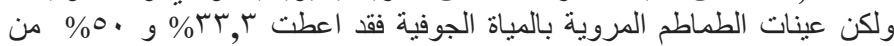

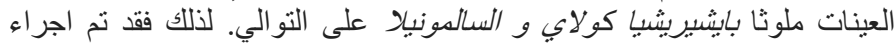

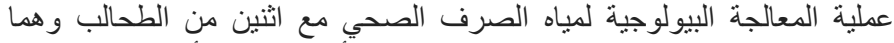

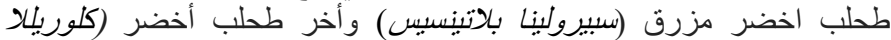

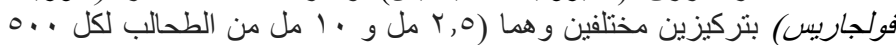

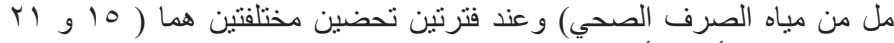

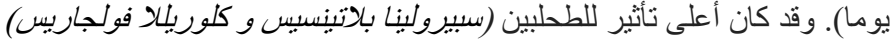

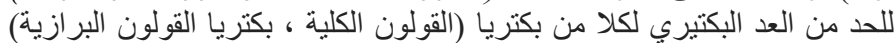

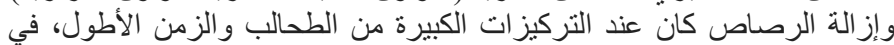

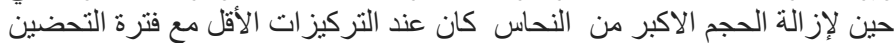

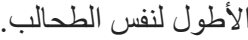

